\title{
Putative Protein Biomarkers of Escherichia coli Antibiotic Multiresistance Identified by MALDI Mass Spectrometry
}

\author{
Telma de Sousa ${ }^{1,2,3,4}$ (D) Didier Viala ${ }^{5}$, Laetitia Théron ${ }^{6}$, Christophe Chambon ${ }^{5,6}$, \\ Michel Hébraud ${ }^{5,7}$, Patricia Poeta ${ }^{2,4}$ and Gilberto Igrejas 1,3,4,* D \\ 1 Department of Genetics and Biotechnology, University of Trás-os-Montes and Alto Douro (UTAD), \\ 5000-801 Vila Real, Portugal; telmaslsousa@hotmail.com \\ 2 Microbiology and Antibiotic Resistance Team (MicroART), Department of Veterinary Sciences, University of \\ Trás-os-Montes and Alto Douro (UTAD), 5000-801 Vila Real, Portugal; ppoeta@utad.pt \\ 3 Functional Genomics and Proteomics Unit, University of Trás-os-Montes and Alto Douro (UTAD), \\ 5000-801 Vila Real, Portugal \\ 4 Associate Laboratory for Green Chemistry (LAQV), Chemistry Department, Faculty of Science and \\ Technology, University Nova of Lisbon, Lisbon, 2829-516 Caparica, Portugal \\ 5 Institut National de Recherche pour l'Agriculture, l'Alimentation et l'Environnement (INRAE), Metabolomic \\ and Proteomic Exploration Facility (PFEMcp), 63122 Saint-Genès-Champanelle, France; \\ didier.viala@inrae.fr (D.V.); christophe.chambon@inrae.fr (C.C.); michel.hebraud@inrae.fr (M.H.) \\ 6 Institut National de Recherche pour l'Agriculture, l'Alimentation et l'Environnement (INRAE), UR Qualité \\ des Produits Animaux (QuaPA), 63122 Saint-Genès-Champanelle, France; laetitia.theron@inrae.fr \\ 7 Université Clermont Auvergne, INRAE, UMR Microbiologie Environnement Digestif Santé (MEDiS), \\ 63122 Saint-Genès-Champanelle, France \\ * Correspondence: gigrejas@utad.pt
}

Received: 26 February 2020; Accepted: 13 March 2020; Published: 19 March 2020

\begin{abstract}
The commensal bacteria Escherichia coli causes several intestinal and extra-intestinal diseases, since it has virulence factors that interfere in important cellular processes. These bacteria also have a great capacity to spread the resistance genes, sometimes to phylogenetically distant bacteria, which poses an additional threat to public health worldwide. Here, we aimed to use the analytical potential of MALDI-TOF mass spectrometry (MS) to characterize E. coli isolates and identify proteins associated closely with antibiotic resistance. Thirty strains of extended-spectrum beta-lactamase producing E. coli were sampled from various animals. The phenotypes of antibiotic resistance were determined according to Clinical and Laboratory Standards Institute (CLSI) methods, and they showed that all bacterial isolates were multi-resistant to trimethoprim-sulfamethoxazole, tetracycline, and ampicillin. To identify peptides characteristic of resistance to particular antibiotics, each strain was grown in the presence or absence of the different antibiotics, and then proteins were extracted from the cells. The protein fingerprints of the samples were determined by MALDI-TOF MS in linear mode over a mass range of 2 to $20 \mathrm{kDa}$. The spectra obtained were compared by using the ClinProTools bioinformatics software, using three machine learning classification algorithms. A putative species biomarker was also detected at a peak $\mathrm{m} / \mathrm{z}$ of 4528.00 .
\end{abstract}

Keywords: antibiotics; bacterial resistance; one health; MALDI-TOF MS; biomarkers

\section{Introduction}

It is estimated that $18 \%$ of the genes present in the genome of Escherichia coli, a commensal bacteria in humans and other animals, come from horizontal transfer from other species over millions of years [1]. Normally, these bacteria are not responsible for the onset of diseases, but when they acquire virulence 
factors, they can cause severe infections. As an additional consequence, these bacteria have a high capacity to propagate and pass these genes on even to phylogenetically distant bacteria [2,3]. With the emergence of new resistances, there has thus been a decrease in the effectiveness of treatments for certain bacterial infections in human and veterinary medicine, causing serious problems worldwide [4].

Antibiotics act in several different ways, such as by inhibiting cell wall biosynthesis, altering cell membrane permeability, interfering in replication and repair of DNA, inhibiting protein synthesis, and inhibiting the biosynthesis of folic acid. The mechanism of action of each antibiotic prevents one or more crucial steps in the cellular processes of the target microorganism essential for its survival $[5,6]$. The inappropriate use of antibiotics can lead to serious problems, especially in some developing countries where there are few health technicians and antibiotics are commonly available for purchase without prescription [7]. Even when the prescription of antibiotics is adequate, the dosage regimens may be too short to eradicate the infection, intensifying the survival of resistant strains [7]. These factors are contributing to the emergence of new and potentially hazardous bacterial strains.

In 1975, Anhalt and Fenselau pioneered the use of mass spectrometry (MS) for the identification of bacteria, and it has proved a powerful tool for identifying the species and the biomarkers of certain diseases [8]. It is also a way of gaining deeper insights into cell events by pinpointing the proteins involved in different cellular processes. Proteomics is now an extremely important way of studying the differential expression of proteins under different environmental conditions, and is leading to the discovery of new biomarkers that are more or less abundant in a state of disease compared to a healthy state $[9,10]$. This technique has been demonstrated to be useful for studying antibiotic resistance in different bacterial strains, especially when determining the metabolic pathways involved [11]. As multi-antibiotic resistant bacteria can hinder the treatment of patients with complex infections, rapid and effective detection of resistance mechanisms may be vital in choosing the best antimicrobial to use. While some proteins related to different antimicrobial resistance mechanisms have been identified, the need to discover new biomarkers has been highlighted [11,12]. This task is challenging because it involves multidisciplinary skills, requiring the collaboration of scientists expert in genetics, molecular biology, biochemistry, mass spectrometry, and bioinformatics [9]. When E. coli biomarkers were characterized by MALDI-TOF MS, most of the biomolecules detected were ribosomal proteins. Many ribosomal proteins are found in the cell envelope subfraction, because they are often located just inside the cell membrane of intact bacteria [13,14]. As biomarkers are discovered, comprehensive information on the nature of proteins and their expression in relation to antimicrobial agents and resistance mechanisms must be stored in curated databases [15].

For this study, the principal aims were to characterize isolates of E. coli by MALDI-TOF MS and then, based on genotypic characterization, to identify and analyze at a statistical level the protein biomarkers associated with the antibiotic profiles of the bacteria and their responses to antibiotics.

\section{Materials and Methods}

\subsection{Samples and Bacterial Strains}

The majority of the E. coli strains used in this work came from animals and were collected in several regions of Portugal and Spain over different periods of time (Table 1). A few strains were collected from human patients at the Gabriel-Montpied University Hospital Centre in Clermont-Ferrand (France). To isolate individual strains, the samples were spread on Petri dishes containing Levine agar supplemented with cefotaxime $(2 \mathrm{mg} / \mathrm{mL})$. After $24 \mathrm{~h}$ of incubation at $37^{\circ} \mathrm{C}$, colonies typical of E. coli were selected, purified, and identified by standard bacteriological methods (i.e., Gram-staining, catalase, oxidase, indol, methyl-red/Voges-Proskauer, citrate, and urease), and by using the API 20E biochemical identification system (bioMérieux, La Balme Les Grottes, France). 
Table 1. Data on the origins of the E. coli strains used in this study.

\begin{tabular}{|c|c|c|c|c|}
\hline Animal & $\begin{array}{l}\text { Number of Animal } \\
\text { Samples Collected }\end{array}$ & $\begin{array}{l}\text { Type of } \\
\text { Samples }\end{array}$ & $\begin{array}{l}\text { Period of } \\
\text { Collected }\end{array}$ & $\begin{array}{c}\text { Geographic Location of } \\
\text { Collection }\end{array}$ \\
\hline Pigs & 71 & Faecal samples & $\begin{array}{l}\text { September } 2008 \text { to } \\
\text { March } 2009\end{array}$ & $\begin{array}{l}\text { Slaughterhouse located in } \\
\text { central Portugal }\end{array}$ \\
\hline Iberian Lynx & 128 & Faecal samples & 2008 to 2010 & $\begin{array}{l}\text { Doniga National Park, } \\
\text { Sierra Morena, and } \\
\text { Southern Spain }\end{array}$ \\
\hline Buteo buteo & 33 & Faecal samples & $\begin{array}{l}\text { September } 2007 \text { to } \\
\text { February } 2008\end{array}$ & $\begin{array}{c}\text { Pêneda do Gerês Natural } \\
\text { Park or others } \\
\text { conservation areas of } \\
\text { Portugal }\end{array}$ \\
\hline Birds of prey & 119 & Faecal samples & $\begin{array}{l}\text { April to July de } \\
2008\end{array}$ & $\begin{array}{l}\text { Center for Ecology, } \\
\text { Recovery and Wildlife } \\
\text { Surveillance }\end{array}$ \\
\hline Boar & 77 & Faecal samples & $\begin{array}{l}\text { December } 2005 \text { to } \\
\text { February } 2007\end{array}$ & North of Portugal \\
\hline Chicken & 22 & $\begin{array}{l}\text { Different parts } \\
\text { of a chicken }\end{array}$ & $\begin{array}{l}\text { September to } \\
\text { December } 2007\end{array}$ & Supermarket in Vila Real \\
\hline
\end{tabular}

\subsection{Antimicrobial Susceptibility Test and Characterization of Resistance Genes}

Thirty recovered E. coli isolates were selected at random and tested using the agar disk diffusion method, as recommended by the Clinical and Laboratory Standards Institute (CLSI) [16]. The antimicrobials tested were streptomycin (STR; $10 \mu \mathrm{g} /$ disk), tetracycline (TET; $30 \mu \mathrm{g} /$ disk), gentamicin (CN; $10 \mu \mathrm{g} /$ disk), tobramycin (TOB; $10 \mu \mathrm{g} /$ disk), kanamycin (K; $30 \mu \mathrm{g} /$ disk), ciprofloxacin (CIP; $5 \mu \mathrm{g} /$ disk), trimethoprim-sulfamethoxazole (SXT; 1.25/23.75 $\mu \mathrm{g} /$ disk), cefoxitin (FOX; $30 \mu \mathrm{g} / \mathrm{disk}$ ), and chloramphenicol (CHL; $30 \mu \mathrm{g} /$ disk). The following antimicrobial resistance genes were studied by PCR, as previously described [17-20]: tet(A) and tet(B) in TET-resistant isolates; aadA and $\operatorname{str} A-\operatorname{str} B$ in STR-resistant isolates; aac(3)-II and aac(3)-IV in CN-resistant isolates; sul1, sul2, and sul3 in SXT-resistant isolates; $c m l A$ in CHL resistant isolates; $b l a_{\mathrm{CTX}-\mathrm{M}}, b l a_{\mathrm{TEM}}$ and $b l a_{\mathrm{SHV}}$ in AMP-resistant isolates (alleles for $b l a_{\mathrm{CTX}-\mathrm{M}}$ were obtained by sequencing in a previous studies); and ampC in FOX-resistant isolates.

\subsection{Proteomics Study}

\subsubsection{Bacterial Culture with and without Antibiotics}

From all the E. coli isolates obtained, 30 were randomly selected $(n=30)$ and seeded in $5 \mathrm{~mL}$ of brain heart infusion liquid (BHI) at $37^{\circ} \mathrm{C}$ for $24 \mathrm{~h}$ to promote bacterial growth and ensure that the bacterial concentration was appropriate and equivalent for all the samples. After $24 \mathrm{~h}$, the bacterial density of cultures was determined, and Petri dishes containing $18 \mathrm{~mL}$ of Levine medium were inoculated with each strain and incubated at $37^{\circ} \mathrm{C}$ for $24 \mathrm{~h}$ to check that the bacterial density was appropriate and equivalent for all the samples. The density was determined from the spectrophotometer, where one to two colonies were removed from the Petri dish and diluted in BHI (in order to decrease the bacterial concentration) until the density was below approximately 0.800 (600 nm wavelength).

CLSI standards were followed for the cultures with the different antibiotics tested [16]. Levine agar medium was supplemented with $1 \mathrm{~mL}$ of antibiotic at the appropriate concentration. The rest of the culture procedure was the same as for cultures without antibiotic.

\subsubsection{MALDI-TOF Mass Spectrometry}

Protein extracts were obtained from intact bacterial cells using a quick method described by [21]. For each E. coli strain, two colonies were transferred at room temperature to separate solutions containing $300 \mu \mathrm{L}$ of distilled water and $900 \mu \mathrm{L}$ of ethanol, then were centrifuged for 2 min at $10,000 \times g$. 
The supernatant was discarded, and the same steps were repeated before drying the pellet at room temperature. The pellet was then vortexed in $10 \mu \mathrm{L}$ of $70 \%$ formic acid until completely dissolved. Then, $10 \mu \mathrm{L}$ of pure acetonitrile were added, and the sample was centrifuged for $2 \mathrm{~min}$ at $10,000 \times g$ and the supernatant recovered. Supernatant $(5 \mu \mathrm{L})$ was mixed with $10 \mu \mathrm{L}$ of matrix solution $(10 \mathrm{mg}$ of $\alpha$-cyano-4-hydroxycinnamic acid in $1 \mathrm{~mL}$ of a solution of $50 \%$ acetonitrile and $2.5 \%$ trifluoroacetic acid).

An aliquot of each sample $(1 \mu \mathrm{L})$ was deposited on the MALDI-TOF MS target (Anchorchip). Calibration was performed by depositing $1 \mu \mathrm{L}$ of a mixture containing $0.5 \mu \mathrm{L}$ of the matrix solution and $0.5 \mu \mathrm{L}$ of Calibrating Protein Standard I solution. The deposits were left to dry on the MALDI-TOF MS target at room temperature. The sample analyses were carried out with an Autoflex Speed mass spectrometer (Bruker Daltonics) using the following parameters: linear mode, positive-ion extraction with voltages of $19.56 \mathrm{kV}$ at source 1 and $18.09 \mathrm{kV}$ at source 2, time delay about $160 \mathrm{~ns}$, and laser intensity to $90 \%$. For each extracted colony, a spectrum was obtained from the sum of three laser shots at the frequency of $1000 \mathrm{~Hz}$. A calibrant spot was analyzed after each isolate analysis by summing four laser shots at the frequency of $1000 \mathrm{~Hz}$.

\subsubsection{Statistics and Bioinformatics}

MALDI-TOF MS of the E. coli samples were analyzed with the ClinProToolsTM software (version 3.0, Bruker Daltonik). This program can be used to recalibrate the spectrum, calculate the average of each spectrum and the peak statistics, and generate models based on the classification algorithm selected. The ClinProTools software includes four types of machine learning algorithms for generating classification models: Quick Classifier (QC), Genetic Algorithm (GA), Supervised Neural Network (SNN), and Support Vector Machine. The spectra selected were submitted to three of these-QC, GA, and SNN-where cross-validation is based on the accuracy of the algorithm in correctly assigning a random sample to the correct group. For each peak, the receiver operating characteristic (ROC) analysis was performed based on the area under the ROC curve (AUC). The AUC measures discrimination, which is the ability of the test to correctly classify positive and negative instances. If the AUC is close to 1 , the test is better.

\section{Results and Discussion}

\subsection{Phenotypic and Genetic Characterization}

By sampling a range of animal and human sources, we detected E. coli strains that are highly resistant or resistant to several antibiotics, which is consistent with previous studies [22-24]. Among the $30 \mathrm{E}$. coli isolates randomly chosen to be studied in more detail, 26 of them were resistant to at least one antibiotic at the phenotypic level. Most isolates showed resistance to trimethoprim-sulfamethoxazole $(n=24)$, tetracycline $(n=19)$, and ampicillin $(n=17)$. In contrast, only a few isolates were resistant to kanamycin $(n=3)$ and gentamicin $(n=2)$. Figure 1 shows the proportions of the 30 isolates, showing phenotypic resistance to the nine antibiotics tested. In a study of E. coli isolates from pigs in Germany, the most common resistance found was against tetracycline in $78.7 \%$ isolates [25], which is similar to the frequency reported here in the isolates from pigs, which was $100 \%$. Although the use of chloramphenicol in cattle husbandry was abolished in Europe in the 1990s, a study in the northwest of England shows that strains of E. coli continue to have an incidence of resistance to this antibiotic, which is often associated with phenotypes of resistance, possibly as part of a multi-resistance system [26]. 


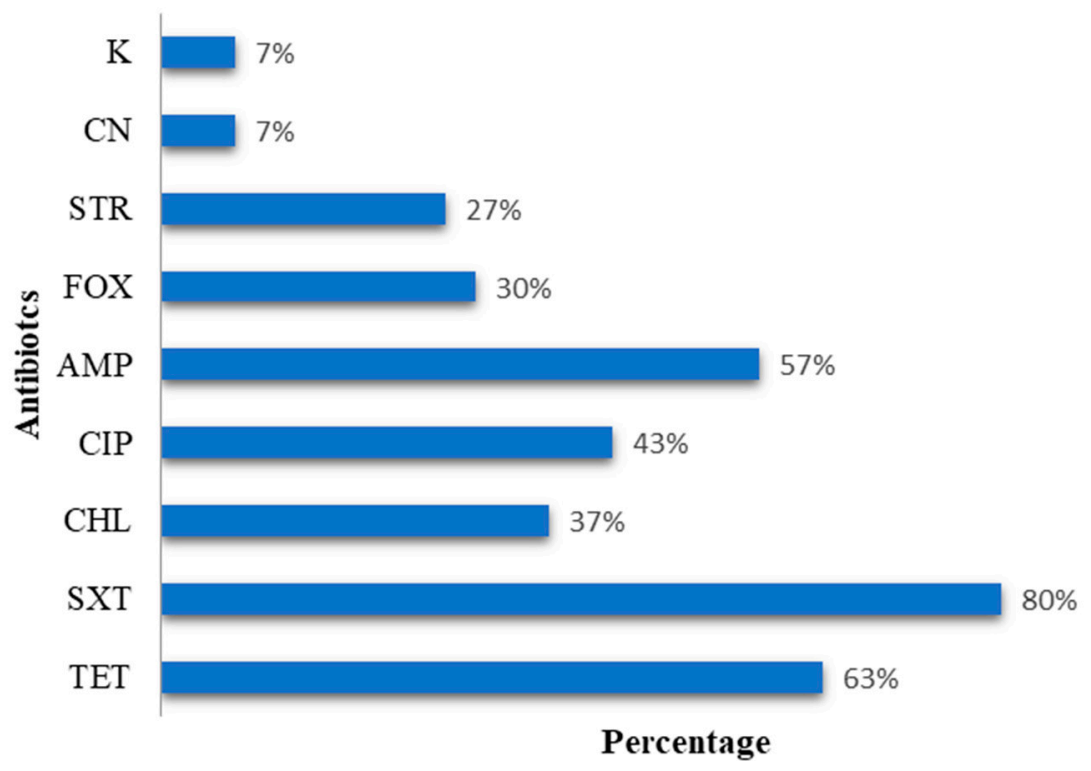

Figure 1. Percentage of phenotypic resistance for E. coli to the different antibiotics tested. It can be seen that more than half of the panel of strains are resistant to trimethoprim-sulfamethoxazole, tetracycline, and ampicillin antibiotics $(80 \%, 63 \%$, and $57 \%$, respectively).

The antimicrobial resistance and the presence of antibiotic resistance genes detected in the E. coli isolates are detailed in Table 2.

The tet(A) gene was found in 13 isolates, while the tet(B) gene was only found in five isolates, which might indicate that the tet(A) gene is the more prevalent. In contrast, Ahmed et al. showed that the $\operatorname{tet}(\mathrm{B})$ gene was more prevalent than the $\operatorname{tet}(\mathrm{A})$ gene. Both tet $(\mathrm{A})$ and $\operatorname{tet}(\mathrm{B})$ genes were found in only two isolates [26].

All the strains encode genes to produce extended-spectrum $\beta$-lactamase (ESBL), confirming that these Gram-negative bacteria are resistant to $\beta$-lactams. In this study, there was a higher prevalence of $b l a_{\mathrm{CTX}-\mathrm{M}}(77 \%)$ compared to $b l a_{\mathrm{SHV}}$ and $b l a_{\mathrm{TEM}}(10 \%$ and $40 \%$, respectively). The rapid dissemination of broad spectrum $\beta$-lactamases is a global emergency for public health. Most ESBL genes are mutants derived from the $\beta$-lactamases bla $a_{\mathrm{SHV}}$ and $b l a_{\mathrm{TEM}}$, but there has been an increasing prevalence of mutations in the gene bla $_{\mathrm{CTX}-\mathrm{M}}$ in Enterobacteriaceae in the last decade [27]. Countries such as Canada, Italy, Spain, Greece, and the United Kingdom have witnessed alarming reports of antimicrobial resistance within ESBL-producing organisms in community locations [28].

Most of the isolates have shown resistance to trimethoprim-sulfamethoxazole and the genes sul1, sul2, and/or sul3 have been identified, confirming the phenotypic test. For example, 12 isolates contained the gene sul2. 
Table 2. Phenotype and resistance genotype of E. coli isolates.

\begin{tabular}{|c|c|c|c|}
\hline Animals & E. coli Isolates & Resistance Phenotype & Resistance Genes \\
\hline Chicken breast & P6A & STR CN SXT CIP & bla $_{T E M-52}$ aadA aac(3)-II sul2 \\
\hline \multirow{2}{*}{ Chicken wings } & A3A & TET SXT & bla $_{\text {CTX-M-1 }}$ tet(B) sul2 \\
\hline & $\mathrm{A} 4 \mathrm{~A}$ & AMP & bla $a_{T E M-52}$ tet $(\mathrm{B})$ \\
\hline Chicken gizzard & M1A & CN SXT CHL & bla ${ }_{C T X-M-14} \mathrm{cmlA}$ aac(3)-II sul3 \\
\hline \multirow[t]{2}{*}{ Chicken skin } & Pe4A & TET SXT & bla $_{T E M-52}$ tet(A) sul sul2 \\
\hline & 13103 & AMP CIP TET K SXT & $b l a_{T E M} b l a_{C T X-M-3}$ tet(A) sul2 \\
\hline \multirow[t]{2}{*}{ Birds of prey } & 1102 & AMP CIP TET K STR SXT & bla $a_{\mathrm{CTX}-\mathrm{M}-3}$ tet(A) sul2 \\
\hline & 2101 & AMP CIP TET K SXT & $b^{b l a_{T E M}} b_{\text {CTX-M-3 }}$ tet(A) sul2 \\
\hline \multirow[t]{3}{*}{ Boar } & $\mathrm{J} 31$ & AMP CIP STR SXT & bla TEM $b_{\text {CTXX-M-3 }}$ sul2 sul3 \\
\hline & SU50 & TET CHL & tet(A) cmlA bla \\
\hline & SU54B & TET SXT CHL & sul3 tet(A) tet(B) cmlA bla ${ }_{\mathrm{CTX}-\mathrm{M}-1}$ \\
\hline \multirow{4}{*}{ Pigs } & SU54C & TET SXT CHL & sul3 tet(A) tet(B) cmlA bla ${ }_{\mathrm{CTX}-\mathrm{M}-1}$ \\
\hline & SU62 & TET & tet(A) bla $_{\mathrm{SHV}-12}$ \\
\hline & SU65 & TET & tet $(\mathrm{B}) b l a_{\mathrm{CTX}-\mathrm{M}-1}$ \\
\hline & SU80 & TET SXT & sul1 sul2 sul3 tet(A) bla $a_{\mathrm{CTX}-\mathrm{M}-1}$ \\
\hline \multirow{3}{*}{ Lynx } & L16 & TET STR & $\operatorname{tet}(\mathrm{A})$ aad $A$ bla $a_{\mathrm{CTX}-\mathrm{M}-14}$ \\
\hline & L98 & STR SXT & sul3 aadA bla ${ }_{\mathrm{SHV}-12}$ \\
\hline & BU10A & AMP TET SXT & $\begin{array}{l}\text { sul1 sul2 sul3 tet(A) bla } \\
\text { bla } a_{\mathrm{CTX}-\mathrm{M}-32}\end{array}$ \\
\hline \multirow[t]{7}{*}{ Buteo buteo } & BU10B & AMP FOX STR TET SXT & $\begin{array}{c}\text { aadA ampC sul1 sul2 sul3 tet(A) } \\
\text { bla } a_{T E M-1} b a_{\mathrm{CTX}-\mathrm{M}-1}\end{array}$ \\
\hline & BU22A & TET STR SXT AMP & $\begin{array}{l}\text { aadA sul1 sul2 sul3 tet(A)bla } a_{T E M-1} \\
\text { bla }_{\mathrm{CTX}-\mathrm{M}-1}\end{array}$ \\
\hline & BU32 & STR & aadA $b l a_{T E M-1} b l a_{\mathrm{CTX}-\mathrm{M}-1}$ \\
\hline & BU41A & TET SXT AMP & sul1 sul2 aadA bla TEM-1 bla \\
\hline & CNR695 & FOX CIP CHL SXT AMP & $b l a_{\mathrm{CTX}-\mathrm{M}-14}$ \\
\hline & CNR2630 & FOX CIP CHL SXT AMP & $b_{\mathrm{SHV}-12}$ \\
\hline & CNR1890 & FOX CIP CHL SXT AMP & $b l a_{\mathrm{CTX}-\mathrm{M}-1}$ \\
\hline \multirow{5}{*}{ Human } & CNR681 & FOX CIP CHL SXT AMP & $b l a_{\mathrm{CTX}-\mathrm{M}-9}$ \\
\hline & CNR742 & FOX CIP CHL SXT AMP TET & $b l a_{\mathrm{CTX}-\mathrm{M}-14}$ \\
\hline & CNR477 & FOX CIP CHL SXT AMP TET & $b l a_{\mathrm{CTX}-\mathrm{M}-14}$ \\
\hline & BLSE176 & FOX CIP CHL SXT AMP & $b l a_{\mathrm{CTX}-\mathrm{M}-32}$ \\
\hline & BLSE119 & FOX CIP CHL SXT AMP TET & $b l a_{\mathrm{CTX}-\mathrm{M}-32}$ \\
\hline
\end{tabular}

TET: tetracycline; AMP: ampicillin; CIP: ciprofloxacin; SXR, trimethoprim: sulfamethoxazole; K: kanamycin; CN: gentamicin; CHL: chloramphenicol; FOX: cefoxitin; STR: streptomycin.

\subsection{Specific Peak for E. coli}

The following MALDI-TOF MS analyses were focused on the proteomics of resistance to trimethoprim-sulfamethoxazole, ciprofloxacin, ampicillin, chloramphenicol and tetracycline, which were the most frequent antibiotic resistances observed in our isolates. For each isolate, the mass spectra were obtained from cells grown with and without the presence of an antibiotic. Most of the peaks obtained from E. coli cultures grown in the presence and absence of antibiotics in the medium have a good resolution. Here, the purpose was not to analyze each isolate itself, but to compare two conditions: the first class represents the isolates that grew in the absence of an antibiotic in the culture medium, and the second class contains the isolates that grew in the culture medium with different antibiotics-that is, they were responding to and resisting the antibiotic.

For all strains of $E$. coli, a peak $m / z$ of 4528.00 was detected, and the AUC values were significant $(\geq 0.80)$, except for those grown in ampicillin, which gave an AUC value of 0.78 (Figure 2). This peak could therefore be considered as characteristic of this bacterial species. On the other hand, another study detected the peaks at $6711.00 \mathrm{~m} / \mathrm{z}$ and $10883.00 \mathrm{~m} / \mathrm{z}$ were chosen as outbreak E. coli strain biomarkers. This variation in the detection of specific peaks may be due to the general spectral variability between endemic strains of E. coli [29]. 


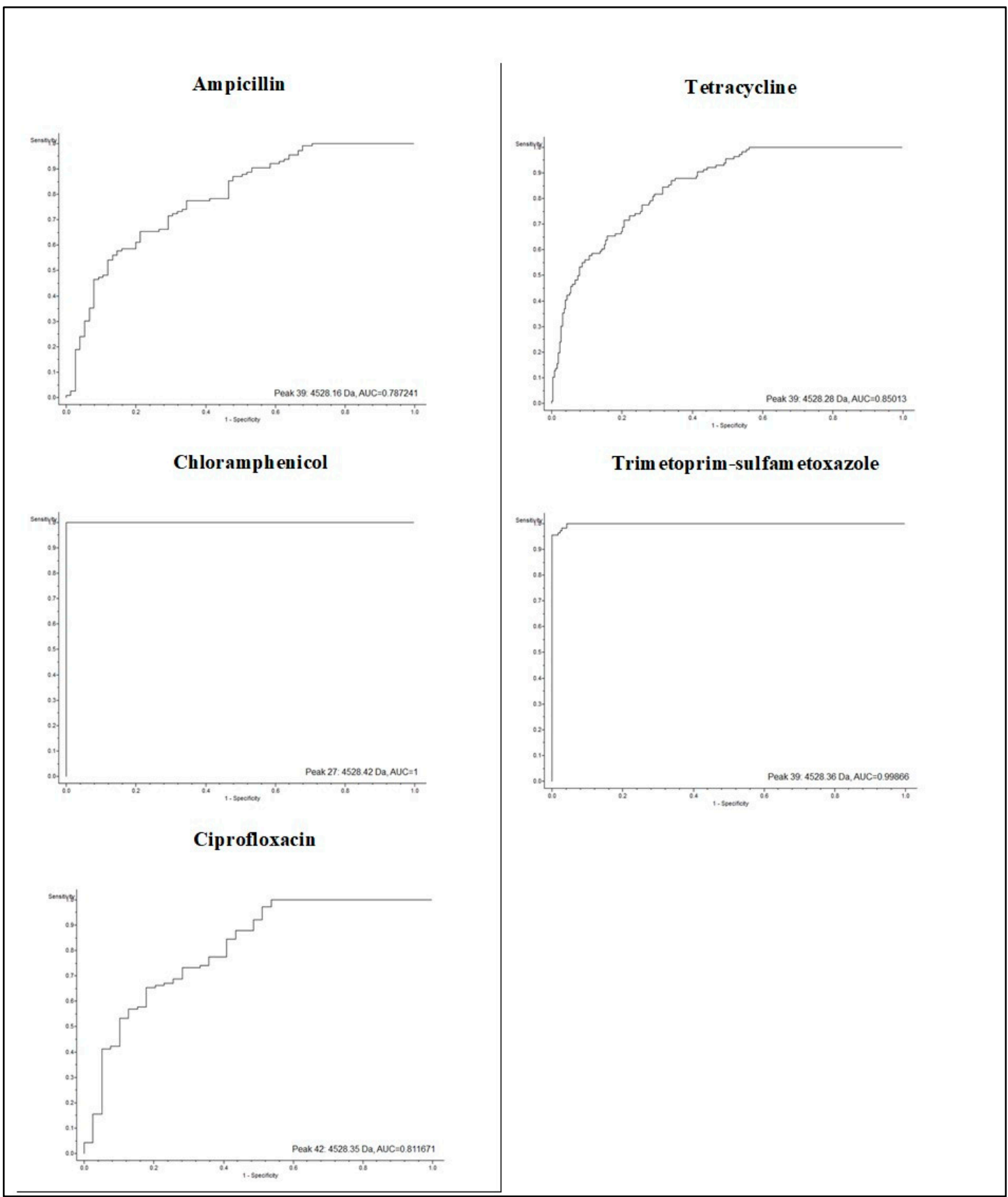

Figure 2. Area under the receiver operating characteristic (ROC) curve (AUC) value for the peak at $4528.42 \mathrm{~m} / \mathrm{z}$ obtained from an E. coli culture grown in the presence of different antibiotics. The ROC curve allows us to know the sensitivity and specificity of a test, and the area evaluates discrimination, which is the ability of the test to correctly classify positive and negative tests.

MALDI-TOF MS has performed well in detecting different bacterial species. The peak at 4448.00 $m / z$ was related to clinical strains of $S$. aureus [30]. The overall correct identification rate of MALDI-TOF MS for anaerobic bacteria ranged from $60 \%$ to $100 \%$ at the genus level, and from $51 \%$ to $100 \%$ at the species level [31]. Thus, this technique is demonstrated to have good functionality in the detection of bacterial species and genera in a rapid way. 


\subsection{Specific Peaks for E. coli Strains Grown in Each Antibiotic}

\subsubsection{Trimethoprim-Sulfamethoxazole and Ampicillin}

For E. coli strains grown in trimethoprim-sulfamethoxazole, we highlighted 37 peaks with the algorithms Genetic Algorithm, Supervised Neural Network, and Quick Classifier, which gave results of $98.63 \%, 98.30 \%$, and $90.99 \%$, respectively. These values were also obtained by cross-validation, thus corroborating the models used. The peaks at $3815.82 \mathrm{~m} / \mathrm{z}, 6112.84 \mathrm{~m} / \mathrm{z}$, and $7160.36 \mathrm{~m} / \mathrm{z}$ (Figure 3) have AUC values of $0.83,0.95$, and 0.96, respectively, and only arise from samples of E. coli grown with this antibiotic. These peaks may therefore correspond to proteins involved in the trimethoprim-sulfamethoxazole resistance mechanism.

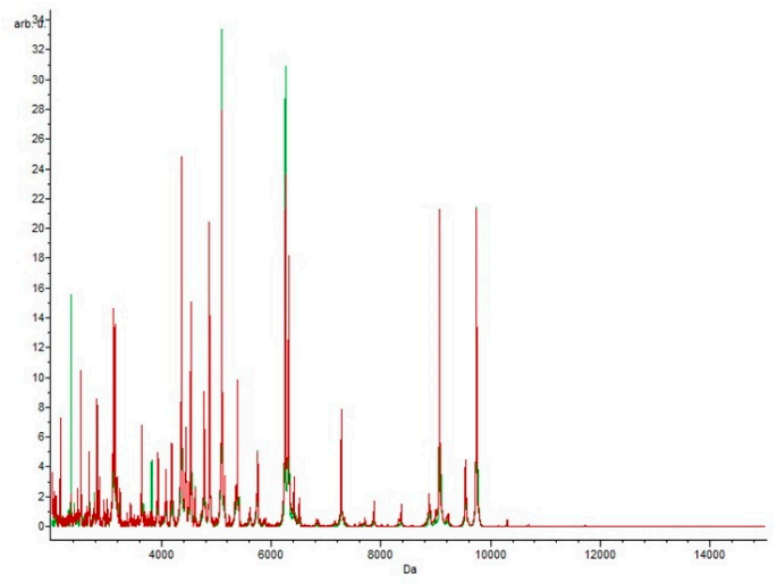

(a)

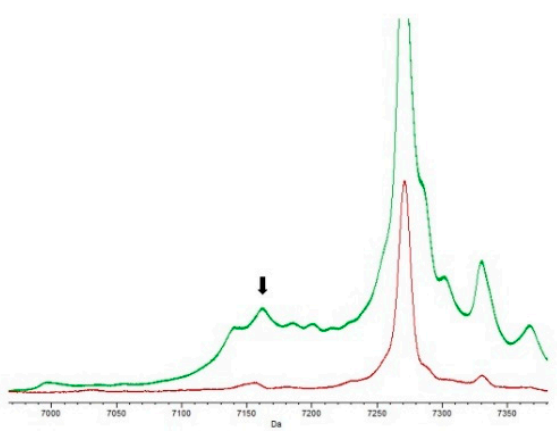

(b)

Figure 3. Peaks at $7160.36 \mathrm{~m} / \mathrm{z}$ : (a) spectrum obtained in the presence of trimethoprim-sulfamethoxazole (green) and (b) zooming in on the peak at $7160.36 \mathrm{~m} / \mathrm{z}$, which is statistically significant ( $p$-value = $0.000001)$ and is specific to cells submitted to the trimethoprim-sulfamethoxazole antibiotic.

\subsubsection{Ampicilin}

The peptide masses $2770.87 \mathrm{~m} / \mathrm{z}, 2943.29 \mathrm{~m} / \mathrm{z}, 3665.49 \mathrm{~m} / \mathrm{z}, 5105.00 \mathrm{~m} / \mathrm{z}$, and $9089.69 \mathrm{~m} / \mathrm{z}$ are exclusive to E. coli exposed to ampicillin, and are absent from the spectra of control samples. Figure 4 shows the characteristics of the $9089.69 \mathrm{~m} / \mathrm{z}$ peak in detail.

The presence of the $2943.29 \mathrm{~m} / \mathrm{z}$ peak may reflect the expression of a protein involved in a specific/particular resistance mechanism. A study by Camara and Hays [32] provides additional evidence that the $2943.29 \mathrm{~m} / \mathrm{z}$ peak can be detected in E. coli samples. The exclusivity of these $\mathrm{m} / \mathrm{z}$ values suggests that this could be considered a specific biomarker for this antibiotic response.

In our work, no peak with a peptide mass associated with the SHV-type $\beta$-lactamases was found in the ampicillin-resistant isolates, which is confirmed by the genotype, as they only had the $b a_{T E M}$ and/or $b l a_{C T X-M}$ genes. The genotype shows one sample with the $b l a_{S H V}$ gene; however, its expression was not sufficiently statistically significant for the detection of this kind of $\beta$-lactamase.

The family of SHV-type $\beta$-lactamases is constantly evolving. Each type of SHV can be distinguished from all other types based on their peptide masses $[33,34]$. We were thus able to associate the mass peaks at $2009.51 \mathrm{~m} / \mathrm{z}$ and $4434.70 \mathrm{~m} / \mathrm{z}$ present in the proteomes of the isolates, which were grown in the presence of trimethoprim-sulfamethoxazole, as $\beta$-lactamases of the SHV type. This data corroborates the genotype obtained in isolates with resistance to this antibiotic and with the masses obtained in the study by Sturenburg et al. [34]. In this sense, the detection of modifications in this family may become crucial in preventing newly emerged resistances from spreading. 


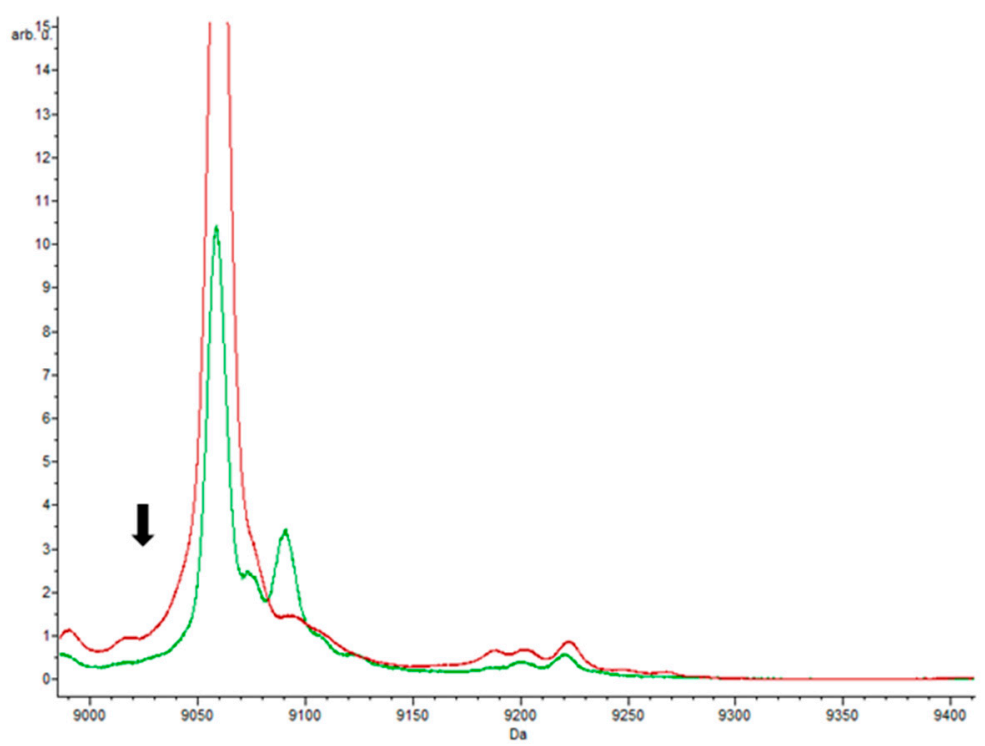

Figure 4. Peaks at $9089.69 \mathrm{~m} / \mathrm{z}$. The characteristic peak obtained with the antibiotic ampicillin (green) vs without antibiotic (red). The $p$-value is 0.0000359 , making this peak statistically significant, and is exclusive to ampicillin antibiotic.

A study developed by Oviaño Marina et al. obtained quite significant positive results in the detection of cefotaxime and ceftazidime hydrolysis for the same incubation time, compared to the use of qualitative spectrum interpretation in ESBL-producing Enterobacteriaceae [35]. However, when comparing the results, there is no direct correlation, since the patterns used in this work (intact proteins) and in the developed work (digested proteins) by Oviaño Marina use different patterns of analysis [35,36]. Nevertheless, the detection of resistance to $\beta$-lactamase mediated by $\beta$-lactamases in clinical samples by MALDI-TOF MS presented a well-studied pathway with increasingly promising results.

\subsubsection{Chloramphenicol}

Two peaks appeared very significant in the proteomes of E. coli grown with chloramphenicol, namely $4866.85 \mathrm{~m} / \mathrm{z}$ and $9059.97 \mathrm{~m} / \mathrm{z}$, both of which had AUC values of 0.99 . Peaks at 9059.97 and $9735.29 \mathrm{~m} / \mathrm{z}$ were both highlighted by the Supervised Neural Network and QuickClassifier algorithms (Figure 5). Although these two peaks also appear in the E. coli proteomes responding to other antibiotics, they are much less intense compared to the control samples. Thus, they can also serve as potential biomarkers of the chloramphenicol response through the marked difference in intensity. Conversely, the peaks with masses of $4395.40 \mathrm{~m} / \mathrm{z}, 5830.14 \mathrm{~m} / \mathrm{z}, 6350.38 \mathrm{~m} / \mathrm{z}$, and $6367.35 \mathrm{~m} / \mathrm{z}$ were only found in the strains that grew in medium with chloramphenicol. Potentially, these peaks could correspond to proteins involved in the mechanism of resistance, since this was the only antibiotic studied that intervenes in the inhibition of protein synthesis through the 50S subunit of the ribosome.

On the other hand, the $9059.97 \mathrm{~m} / \mathrm{z}$ peak was found in almost all E. coli isolates, which may correspond to the mass of a protein involved in the basal metabolism of the bacterium and is not specific to the cellular response to chloramphenicol. The same peptide mass was found in other E. coli strains from humans, cows, and Shigella flexneri [37,38]. However, the latter peak was not detected in cells growing in the presence of ciprofloxacin, which raises some questions about how the protein might function. 


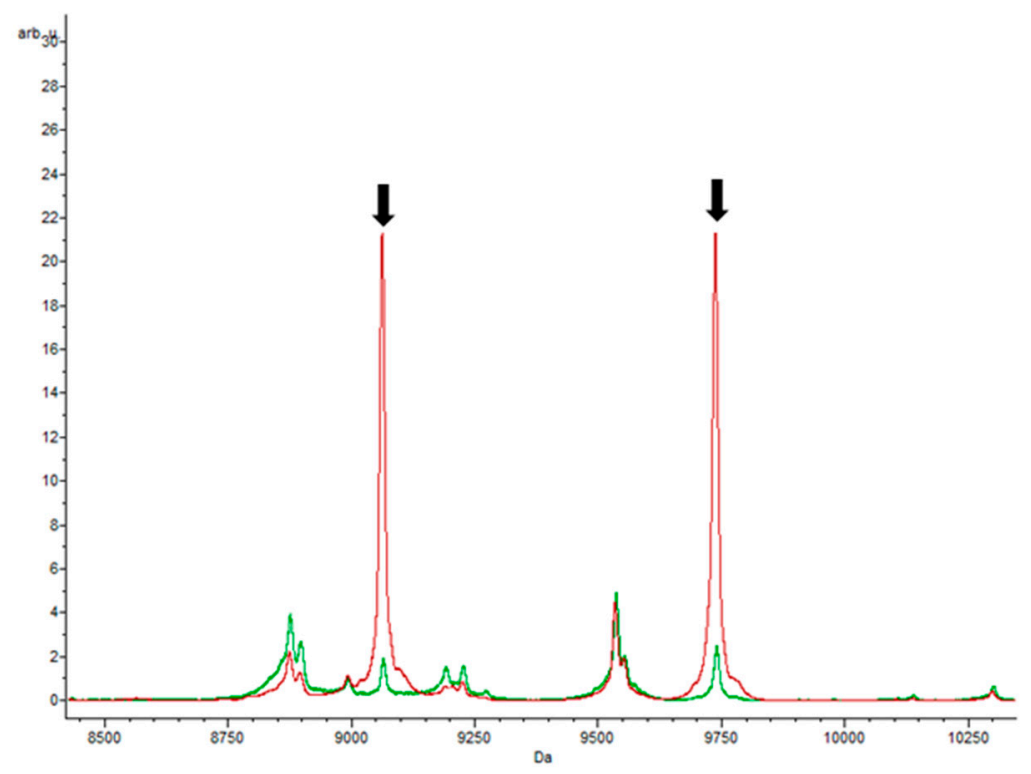

Figure 5. Peaks obtained with chloramphenicol. Spectra obtained in the presence of antibiotic (green) and without antibiotic (red). The results showed statistically significant peaks ( $p$-value $=0.000001$ ), with masses of 9059.97 and $9735.29 \mathrm{~m} / z$, respectively.

\subsubsection{Tetracycline}

Tetracycline was the antibiotic which gave rise to the fewest specific peaks, according to this machine learning approach. Only the $3665.79 \mathrm{~m} / \mathrm{z}$ peak was highlighted by two sorting algorithms; other putative peaks were only detected by a single algorithm. Nevertheless, results with cross-validation of model generation were $88.43 \%, 79.41 \%$, and $75.17 \%$ for Genetic Algorithm, Supervised Neural Network, and Quick Classifier, respectively, showing that the peaks were indeed accurately detected even if only by one algorithm. Peaks reported by Sturenburg et al. for the strains exposed to tetracycline were not observed here [34]. These tetracycline-producing streptomyces present important signal and protein spectra in the mass range of 2 to $20 \mathrm{kDa}$. The mass spectrum of tetracycline (dissolved in ethanol) $(\mathrm{M}+\mathrm{H}+)$ was found at $445.41 \mathrm{~m} / \mathrm{z}$ [39]. This study can be an anchor point for our study, since the detection of specific peaks for tetracycline in our work did not achieve final results when compared to other antibiotics.

\subsubsection{Ciprofloxacin}

A total of 25 peaks were detected in protein extracts from E. coli strains grown in the presence of ciprofloxacin. One of these peaks, the $6312.78 \mathrm{~m} / \mathrm{z}$ peak, was highlighted by all three classification algorithms. This peak was also identified in the control samples, but at a lesser intensity. Three other peaks were found with at least two of the three algorithms. There was strong expression of proteins in the range of 3000 to $4000 \mathrm{~m} / \mathrm{z}$, and the masses $2359.22 \mathrm{~m} / \mathrm{z}, 3432.73 \mathrm{~m} / \mathrm{z}, 3503.91 \mathrm{~m} / \mathrm{z}, 3698.04 \mathrm{~m} / \mathrm{z}, 3785.80$ $\mathrm{m} / \mathrm{z}$, and $5791.25 \mathrm{~m} / \mathrm{z}$ only appeared in samples from bacteria grown in the presence of ciprofloxacin. Of all the antibiotics studied, ciprofloxacin was the only one that did not induce a spectrum with peaks similar to those induced by other antibiotics, which had higher peptide masses. The peak at $3785.8 \mathrm{~m} / \mathrm{z}$ is illustrated in Figure 6. 


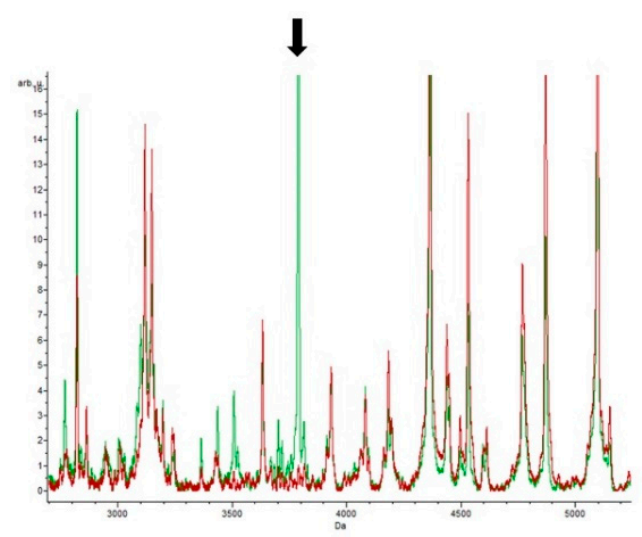

(a)

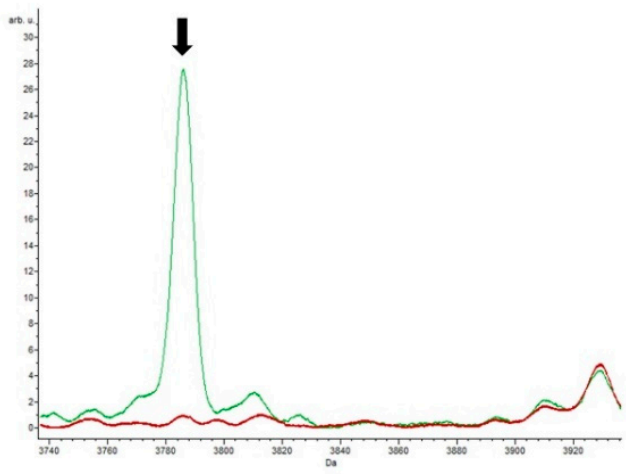

(b)

Figure 6. Ciprofloxacin antibiotic: (a) spectrum obtained in the presence of ciprofloxacin (green) and without antibiotic (red); (b) a detail of the main peak of interest at $3785.80 \mathrm{~m} / \mathrm{z}$.

For the aminoglycoside class of antibiotics, it was not possible to carry out the MALDI-TOF MS study, because there were not enough isolates with this type of resistance for a statistically sound analysis.

E. coli strains susceptible to polymyxin have been reported to be the negative mass spectrum found between 1600 to $2200 \mathrm{Da}$ [40]. Although this study did not include the latest generation of antibiotics, such as polymyxins, daptomycin, or glycylcyclines, there have been studies already focused on some of these antibiotics, namely polymyxins in Gram-negatives. When compared to our control samples (without the addition of antibiotics), we founded that we had very residual peaks in that range. Therefore, compared to this study, our samples may be susceptible to this antibiotic. The authors also showed that in all strains of E. coli resistant to polymyxin, an additional peak of 1919.20 Da was observed regardless of the resistance mechanism involved (encoded by the chromosome or plasmid) [40]. In our study, this peak was not detected in any strain, proving once again that the strains are sensitive to this antibiotic. Regardless, further studies are needed for this antibiotic, because no experiment with polymyxin has been carried out, and the conclusions drawn in this work are preliminary, and only by comparison with other studies.

\section{Conclusions}

The present study brings a new perspective on antibiotic resistance and the normal functioning of the bacterial cell by obtaining more detailed proteomic information about resistances. Few studies have previously used MALDI-TOF MS for the detection of peaks that are specific to exposure to individual antibiotics. Despite being a preliminary study in the detection of putative protein biomarkers, the MALDI-TOF MS technique is here shown to have a high potential in the identification of potential biomarkers for the resistance responses to different antibiotics, especially for trimethoprim-sulfamethoxazole and chloramphenicol, in E. coli. This will pave the way for future research on the prevalence of antibiotic-resistant bacteria in various animals, focusing on the direct and indirect effects of these bacteria in our ecosystem and the evaluation of long-term effects on the animal and human population. MALDI-TOF MS, in combination with the processing and statistical analysis of the mass spectrum obtained for the different antibiotics, may contribute to a technique of identification for routine bacterial multidrug resistance.

It is expected that with the advent of this type of technology, the identification of specific mechanisms of resistance will be facilitated to improve and accelerate patient diagnosis and treatment. To go beyond the simple observation of mass peaks of interest, the corresponding proteins will have to be identified to better understand the fundamental pathways of antibiotic resistance. 
Author Contributions: T.d.S. carried out laboratory work, data analysis, and drafted the manuscript. The final version was written through contributions of all authors. P.P. was responsible for the provision of study materials. T.d.S., D.V., L.T., C.C., M.H., P.P., and G.I. implemented data analyses and helped to draft the manuscript. G.I. conceived the experimental design and project administration. D.V., L.T., C.C., and M.H. helped interpret compiled data. M.H. and G.I. provided facilities and helped implement the laboratory work. D.V., L.T., and C.C. performed the mass spectrometry procedures. All authors have read and agreed to the published version of the manuscript.

Funding: This research was funded by the "Espectrometria de massa e sequenciação aplicadas à microbiologia clínica moderna: pesquisa e identificação de biomarcadores em espécies bacterianas multiresistentes" (Programa de Acções Universitárias Integradas Luso-Francesas, Ação n. ${ }^{\circ}$ : TC-14/2017). This work was supported by the Associate Laboratory for Green Chemistry-LAQV which is financed by national funds from FCT/MCTES (UIDB/50006/2020).

Acknowledgments: In this section you can acknowledge any support given which is not covered by the author contribution or funding sections. This may include administrative and technical support, or donations in kind (e.g., materials used for experiments).

Conflicts of Interest: The authors declare that the research was conducted in the absence of any commercial or financial relationships that could be construed as a potential conflict of interest.

\section{References}

1. Alberts, B.; Johnson, A.; Lewis, J.; Morgan, D.; Raff, M.; Roberts, K.; Walter, P.; Wilson, J.; Hunt, T. Biologia Molecular da Célula; Artmed Editora: Porto Alegre, Brazil, 2010.

2. Costa, D.; Poeta, P.; Saenz, Y.; Vinue, L.; Rojo-Bezares, B.; Jouini, A.; Zarazaga, M.; Rodrigues, J.; Torres, C. Detection of Escherichia coli harbouring extended-spectrum beta-lactamases of the CTX-M, TEM and SHV classes in faecal samples of wild animals in Portugal. J. Antimicrob. Chemother. 2006, 58, 1311-1312. [CrossRef] [PubMed]

3. Martel, A.; Devriese, L.A.; Decostere, A.; Haesebrouck, F. Presence of macrolide resistance genes in streptococci and enterococci isolated from pigs and pork carcasses. Int. J. Food Microbiol. 2003, 84, 27-32. [CrossRef]

4. Radhouani, H.; Silva, N.; Poeta, P.; Torres, C.; Correia, S.; Igrejas, G. Potential impact of antimicrobial resistance in wildlife, environment and human health. Front. Microbiol 2014, 5, 23. [CrossRef] [PubMed]

5. Levy, S.B.; Marshall, B. Antibacterial resistance worldwide: Causes, challenges and responses. Nat. Med. 2004, 10, S122-S129. [CrossRef]

6. Soares, G.M.; Figueiredo, L.C.; Faveri, M.; Cortelli, S.C.; Duarte, P.M.; Feres, M. Mechanisms of action of systemic antibiotics used in periodontal treatment and mechanisms of bacterial resistance to these drugs. J. Appl. Oral Sci. 2012, 20, 295-309. [CrossRef]

7. Tortora, G.J.; Funke, B.R.; Case, C.L. Introducción a la Microbiología; Ed. Médica Panamericana: Ciudad de México, México, 2007.

8. Geyer, P.E.; Holdt, L.M.; Teupser, D.; Mann, M. Revisiting biomarker discovery by plasma proteomics. Mol. Syst. Biol. 2017, 13, 942. [CrossRef]

9. Sigdel, T.K.; Sarwal, M.M. The proteogenomic path towards biomarker discovery. Pediatric Transpl. 2008, 12, 737-747. [CrossRef]

10. Veenstra, T.D. Global and targeted quantitative proteomics for biomarker discovery. J. Chromatogr. B Anal. Technol. Biomed. Life Sci. 2007, 847,3-11. [CrossRef]

11. Radhouani, H.; Pinto, L.; Poeta, P.; Igrejas, G. After genomics, what proteomics tools could help us understand the antimicrobial resistance of Escherichia coli? J. Proteom. 2012, 75, 2773-2789. [CrossRef]

12. Wang, H.Y.; Lien, F.; Liu, T.P.; Chen, C.H.; Chen, C.J.; Lu, J.J. Application of a MALDI-TOF analysis platform (ClinProTools) for rapid and preliminary report of MRSA sequence types in Taiwan. PeerJ 2018, 6, e5784. [CrossRef]

13. Krause, E.; Wenschuh, H.; Jungblut, P.R. The dominance of arginine-containing peptides in MALDI-derived tryptic mass fingerprints of proteins. Anal. Chem. 1999, 71, 4160-4165. [CrossRef] [PubMed]

14. Ryzhov, V.; Fenselau, C. Characterization of the protein subset desorbed by MALDI from whole bacterial cells. Anal. Chem. 2001, 73, 746-750. [CrossRef] [PubMed]

15. Lee, J.M.; Han, J.J.; Altwerger, G.; Kohn, E.C. Proteomics and biomarkers in clinical trials for drug development. J. Proteom. 2011, 74, 2632-2641. [CrossRef] [PubMed]

16. CLSI. Standards for Antimicrobial Susceptibility Testing; Clinical and Laboratory Standards Institute: Wayne, PA, USA, 2017. 
17. Schnellmann, C.; Gerber, V.; Rossano, A.; Jaquier, V.; Panchaud, Y.; Doherr, M.G.; Thomann, A.; Straub, R.; Perreten, V. Presence of new mecA and $\mathrm{mph}(\mathrm{C})$ variants conferring antibiotic resistance in Staphylococcus spp. isolated from the skin of horses before and after clinic admission. J. Clin. Microbiol. 2006, 44, 4444-4454. [CrossRef]

18. Pagani, L.; Dell'Amico, E.; Migliavacca, R.; D'Andrea, M.M.; Giacobone, E.; Amicosante, G.; Romero, E.; Rossolini, G.M. Multiple CTX-M-type extended-spectrum beta-lactamases in nosocomial isolates of Enterobacteriaceae from a hospital in northern Italy. J. Clin. Microbiol. 2003, 41, 4264-4269. [CrossRef]

19. Caroff, N.; Espaze, E.; Berard, I.; Richet, H.; Reynaud, A. Mutations in the ampC promoter of Escherichia coli isolates resistant to oxyiminocephalosporins without extended spectrum beta-lactamase production. FEMS Microbiol. Lett. 1999, 173, 459-465. [CrossRef]

20. Saenz, Y.; Brinas, L.; Dominguez, E.; Ruiz, J.; Zarazaga, M.; Vila, J.; Torres, C. Mechanisms of resistance in multiple-antibiotic-resistant Escherichia coli strains of human, animal, and food origins. Antimicrob. Agents Chemother. 2004, 48, 3996-4001. [CrossRef]

21. Freiwald, A.; Sauer, S. Phylogenetic classification and identification of bacteria by mass spectrometry. Nat. Protoc. 2009, 4, 732-742. [CrossRef]

22. Irenge, L.M.; Ambroise, J.; Bearzatto, B.; Durant, J.F.; Chirimwami, R.B.; Gala, J.L. Whole-genome sequences of multidrug-resistant Escherichia coli in South-Kivu Province, Democratic Republic of Congo: Characterization of phylogenomic changes, virulence and resistance genes. BMC Infect. Dis. 2019, 19, 137. [CrossRef]

23. Santos, T.; Capelo, J.L.; Santos, H.M.; Oliveira, I.; Marinho, C.; Goncalves, A.; Araujo, J.E.; Poeta, P.; Igrejas, G. Use of MALDI-TOF mass spectrometry fingerprinting to characterize Enterococcus spp. and Escherichia coli isolates. J. Proteom. 2015, 127, 321-331. [CrossRef]

24. Taghadosi, R.; Shakibaie, M.R.; Hosseini-Nave, H. Antibiotic resistance, ESBL genes, integrons, phylogenetic groups and MLVA profiles of Escherichia coli pathotypes isolated from patients with diarrhea and farm animals in south-east of Iran. Comp. Immunol. Microbiol. Infect. Dis. 2019, 63, 117-126. [CrossRef] [PubMed]

25. Enne, V.I.; Cassar, C.; Sprigings, K.; Woodward, M.J.; Bennett, P.M. A high prevalence of antimicrobial resistant Escherichia coli isolated from pigs and a low prevalence of antimicrobial resistant $E$. coli from cattle and sheep in Great Britain at slaughter. FEMS Microbiol. Lett. 2008, 278, 193-199. [CrossRef] [PubMed]

26. Ahmed, M.O.; Clegg, P.D.; Williams, N.J.; Baptiste, K.E.; Bennett, M. Antimicrobial resistance in equine faecal Escherichia coli isolates from North West England. Ann. Clin. Microbiol. Antimicrob. 2010, 9, 12. [CrossRef] [PubMed]

27. Memariani, M.; Najar Peerayeh, S.; Zahraei Salehi, T.; Shokouhi Mostafavi, S.K. Occurrence of SHV, TEM and CTX-M beta-lactamase genes among enteropathogenic Escherichia coli strains isolated from children with diarrhea. Jundishapur J. Microbiol. 2015, 8, e15620. [CrossRef]

28. Pitout, J.D.; Nordmann, P.; Laupland, K.B.; Poirel, L. Emergence of Enterobacteriaceae producing extended-spectrum beta-lactamases (ESBLs) in the community. J. Antimicrob. Chemother. 2005, 56, 52-59. [CrossRef] [PubMed]

29. Christner, M.; Trusch, M.; Rohde, H.; Kwiatkowski, M.; Schluter, H.; Wolters, M.; Aepfelbacher, M.; Hentschke, M. Rapid MALDI-TOF mass spectrometry strain typing during a large outbreak of Shiga-toxigenic Escherichia coli. PLoS ONE 2014, 9, e101924. [CrossRef] [PubMed]

30. Bittar, F.; Ouchenane, Z.; Smati, F.; Raoult, D.; Rolain, J.M. MALDI-TOF-MS for rapid detection of staphylococcal Panton-Valentine leukocidin. Int. J. Antimicrob. Agents 2009, 34, 467-470. [CrossRef]

31. Li, Y.; Shan, M.; Zhu, Z.; Mao, X.; Yan, M.; Chen, Y.; Zhu, Q.; Li, H.; Gu, B. Application of MALDI-TOF MS to rapid identification of anaerobic bacteria. BMC Infect. Dis. 2019, 19, 941. [CrossRef]

32. Camara, J.E.; Hays, F.A. Discrimination between wild-type and ampicillin-resistant Escherichia coli by matrix-assisted laser desorption/ionization time-of-flight mass spectrometry. Anal. Bioanal. Chem. 2007, 389, 1633-1638. [CrossRef]

33. Bonardi, S.; Cabassi, C.S.; Longhi, S.; Pia, F.; Corradi, M.; Gilioli, S.; Scaltriti, E. Detection of extended-spectrum beta-lactamase producing Escherichia coli from mesenteric lymph nodes of wild boars (Sus scrofa). Ital. J. Food Saf. 2018, 7, 7707. [CrossRef]

34. Sturenburg, E.; Storm, N.; Sobottka, I.; Horstkotte, M.A.; Scherpe, S.; Aepfelbacher, M.; Muller, S. Detection and genotyping of SHV beta-lactamase variants by mass spectrometry after base-specific cleavage of in vitro-generated RNA transcripts. J. Clin. Microbiol. 2006, 44, 909-915. [CrossRef] [PubMed] 
35. Oviano, M.; Gomara, M.; Barba, M.J.; Revillo, M.J.; Barbeyto, L.P.; Bou, G. Towards the early detection of beta-lactamase-producing Enterobacteriaceae by MALDI-TOF MS analysis. J. Antimicrob. Chemother. 2017, 72, 2259-2262. [CrossRef] [PubMed]

36. Sparbier, K.; Schubert, S.; Weller, U.; Boogen, C.; Kostrzewa, M. Matrix-assisted laser desorption ionization-time of flight mass spectrometry-based functional assay for rapid detection of resistance against beta-lactam antibiotics. J. Clin. Microbiol. 2012, 50, 927-937. [CrossRef]

37. Holland, R.D.; Duffy, C.R.; Rafii, F.; Sutherland, J.B.; Heinze, T.M.; Holder, C.L.; Voorhees, K.J.; Lay, J.O., Jr. Identification of bacterial proteins observed in MALDI TOF mass spectra from whole cells. Anal. Chem. 1999, 71, 3226-3230. [CrossRef] [PubMed]

38. Siegrist, T.J.; Anderson, P.D.; Huen, W.H.; Kleinheinz, G.T.; McDermott, C.M.; Sandrin, T.R. Discrimination and characterization of environmental strains of Escherichia coli by matrix-assisted laser desorption/ionization time-of-flight mass spectrometry (MALDI-TOF-MS). J. Microbiol. Methods 2007, 68, 554-562. [CrossRef]

39. Hleba, L.; Charousova, I.; Cisarova, M.; Kovacik, A.; Kormanec, J.; Medo, J.; Bozik, M.; Javorekova, S. Rapid identification of Streptomyces tetracycline producers by MALDI-TOF mass spectrometry. J. Environ. Sci. Health. Part A Toxic Hazard. Subst. Environ. Eng. 2018, 53, 1083-1093. [CrossRef]

40. Dortet, L.; Bonnin, R.A.; Pennisi, I.; Gauthier, L.; Jousset, A.B.; Dabos, L.; Furniss, R.C.D.; Mavridou, D.A.I.; Bogaerts, P.; Glupczynski, Y.; et al. Rapid detection and discrimination of chromosome-and MCR-plasmid-mediated resistance to polymyxins by MALDI-TOF MS in Escherichia coli: The MALDIxin test. J. Antimicrob. Chemother. 2018, 73, 3359-3367. [CrossRef]

(C) 2020 by the authors. Licensee MDPI, Basel, Switzerland. This article is an open access article distributed under the terms and conditions of the Creative Commons Attribution (CC BY) license (http://creativecommons.org/licenses/by/4.0/). 